\title{
Prognostication algorithms and predictability ranges of mass reproduction of harmful insects according to the method of nonliner dynamics
}

\author{
S. V. Stankevych*, Ye. M. Biletskyj, I. V. Zabrodina, M. D. Yevtushenko, H. V. Baidyk, \\ I. P. Lezhenina, M. O. Filatov, L. Ya. Sirous, D. D. Yushchuk, V. O. Melenti, O. A. Molchanova, \\ L. V. Zhukova, I. V. Nepran, O. V. Romanov, T. A. Romanova, O. M. Bragin \\ V.V. Dokuchaev Kharkiv National Agrarian University \\ v. Dokuchaevske, Kharkiv region, 62483, Ukraine \\ *Corresponding author E-mail: sergejstankevich1986@gmail.com.
}

Received: 19.12.2019. Accepted 25.01.2020

\begin{abstract}
The authors have analysed the theoretical possibilities of prognostication the dynamics in the number and mass reproduction of some species of harmful insects. A theoretical synthesis of the information on the regularities of the population dynamics of the most common insect pests of agricultural plants from the point of view of the methodology of nonlinear dynamics and synergetics has been done. Based on the past and present an analysis of the many-year dynamics in the number of the insect populations has been carried out and an attempt to develop the algorithms for prognostication the seasonal and annual changes in the number of the insects has been made. To do this the authors recommend a scenario-based method of prognostication and making decisions in plant protection. Using the phytosanitary monitoring they determine the beginning of the regular mass reproduction (the appearance of an aggravated rate) and then, based on the phytosanitary prognosis, an aggravation of the situation that has developed or is being developing on the farm, in the district or in the region is made; after that on the base of the short-term prognosis (signaling) it is recommended to make the optimal decision to protect a particular crop taking into account the economic threshold of harmfulness. According to the authors this approach, based on the methodology of nonlinear dynamics (synergetic paradigm), makes it possible to determine in advance the breeding grounds of the aggravated rates and make the optimal decisions in plant protection. The predicted scenario will not be a prognostication of the future, but the elements of an evolutionary process inherent in nature.

Key words: population dynamics, population cycles, insects number, synergetic approach, nonlinear dynamics, prognostication.
\end{abstract}

\section{Introduction}

According to the classical (linear) methodology the dynamics of the populations is the changes in the number and population structure (organization) of the insects in space and time depending on abiotic and biotic factors. Moreover the changes can be predicted both in the perspective and in retrospective. In such a way the prognostication in plant protection is oriented when developing the annual and of many years prognoses in Ukraine. And if the prognoses are not justified or the outbreaks of the mass reproduction of some widespread species of harmful insects occur "unexpectedly" then the search for the possible causes will begin. The methodology to solve the "aggravated problems" from the non-traditional point of view considers a number of classical problems not only in meteorology (the catastrophic phenomena in the Earth's atmosphere, namely the severe droughts), but also in ecology. Moreover the influence of small disturbances varies depending not only on a number of factors but also on the stage of the process development (mass reproduction) and on the location whether it falls into the centre of the population localization or on its periphery. The mass disturbance may not play any role in general and is completely "forgotten" if at the quasistationary stage it falls on the periphery of the structure (the periphery of the geographic or local range of population).

\section{Materials and methods}

By means of the theoretical synthesis of the information as for the regularities of the population dynamics of some insect pests of agricultural plants based on the past and present the analysis of the many-year dynamics in the number of the insect populations is carried out and an attempt to develop the algorithms for predicting the seasonal and annual changes in the number of the insects is made. For this purpose the scenario method of prognostication and decision-making in plant protection was used.

\section{Results and Discussion}

\section{Algorithmus for prognostication the beginning of the regular mass reproduction of some insect pests in Ukraine}

Winter moth. The mass reproduction of thi pest took place in 1823-1825, 1836-1840, 1846-1850, 1861-1863, 1871-1873, 1880-1881, 1893-1836, 1899-1900, 1907-1908, 1918, 1923-1925, 1935-1937, 1946-1950, 1956-1957, 1964-1968, 1971-1973, 1981-1984, 19971998 and in 2007-2008. The average period between the beginnings of the regular mass reproduction was 9 years. Of the 20 mass reproductions of the winter moth 19 occurences that constitute $95 \%$ took place during the years of the sharp changes in the solar activity, and one occurrence (5\%) took place a year later in 1846-1850. The last mass reproduction of this pest was in 2007-2008. The maximum abundance of this pest was in 2007 (the year of the severe drought); if to add 9 years (the average studies) then it will turn 
out that the regular mass reproduction should be expected in 2016-2017 (that is $2016+1$ year), and most likely it will happen in 2018 (Biletskyi, 2011; Biletskyi, Stankevych, 2018).

The most severe drought was in Europe in July and August in 2017. According to the fundamental laws of nonequilibrium thermodynamics and synergetics the aggravated rate may occur after the drought; moreover such occurrences, namely the mass reproductions of the winter moth, were in 1918. The wandering of the mass reproductions within the range of population was observed not only in Ukraine, but also in England, Africa, Bulgaria, Hungary, Germany, Egypt, Russia and Czechoslovakia (Biletskyi, 2011; Biletskyi, Stankevych, 2018).

Webworm beetle. The mass reproduction of thi pest took place in 1855, 1869, 1880, 1901, 1912-1913, 1920-1921, 1929-1932, 19351936, 1956, 1975, 1986-1988 and in 2011-2013. The average period between the beginnings of the regular mass reproduction was 13 years. Of 12 occurences of the mass reproduction 11 ones (92\%) began exactly during the years of the sharp changes in the solar activity, and only one was a year later in 8169. The last mass reproduction of the webworm beetle in Ukraine took place in 2011-2013. The maximum abundance of this pest was in 2013 which means that the regular mass reproduction should be expected in 13 years, i.e. starting with 2026 .

It is possible that the most severe drought of 2017 can cause the resonant disturbance of non-linear dynamics of the webworm beetle and its mass reproduction will begin approximately in 2018 (Biletskyi, 2011; Biletskyi, Stankevych, 2018).

Corn ground beetle. The mass reproduction of this pest took place in 1863-1864, 1880-1881, 1903-1905, 1923-1925, 1931-1932, 19461947, 1952-1953, 1957-1959, 1963-1964, 1966-1967, 1979-1984, 1991-1992 and in 2003-2007. The average period between the beginnings of the regular mass reproduction was 11 years. Of 13 occurences of the mass reproduction 12 ones (92\%) began exactly during the years of the sharp changes in the solar activity, and only one was a year later in 1863. The last mass reproduction of the corn ground beetle in Ukraine took place in 2003-2007. The maximum abundance of this pest was in 2007 which means that the regular mass reproduction should be expected in 11 years, i.e. starting with 2018 (Biletskyi, 2011; Biletskyi, Stankevych, 2018).

Scarab beetles. Their mass reproductions took place in the Forest and Forest-Steppe region of Ukraine in 1840-1842, 1845-1846, 1856$1857,1860-1861,1868-1869,1879-1880,1886-1887,1962-1964,1966-1969,1980-1984$ and in 2003-2007. The average period is 10 years. $82 \%$ of the mass reproductions began exactly during the years of the sharp changes in the solar activity and $18 \%$ began a year later. Their number reached its maximum in 2007; if to add 10 years ahd then 1 year more then their regular mass reproduction should be expedcted starting with 2018 (Biletskyi, 2011; Biletskyi, Stankevych, 2018).

Sun pest. During 118 years (1890-2008) in Ukraine there were 11 mass reproductions of this pest with an average period of 11 years between them. 8 (73\%) of them took place during the years of the sharp changes in the solar activity and 3 occurences (27\%) took place a year later. The last mass reproduction of the sun pests was in 2008-2009. Their number reached its maximum in 2009. In 11-12 years (in 2020-2021) we should expect the beginning of the regular mass reproduction of the scarab beetles (Biletskyi, 2011; Biletskyi, Stankevych, 2018).

Beet root weevil. Its mass reproduction in the beet-growing zone of Ukraine took place in 1851-1855, 1868-1869, 1875-1877, 18801881, 1892-1893, 1896-1897, 1904-1906, 1911-1912, 1920-1922, 1928-1930, 1936-1940, 1947-1949, 1952-1957, 1963-1964, 1973$1976,1986-1988,1998-2000$ and in 2010-2012. The average period is 9 years. Of 18 occurences of the mass reproduction 16 ones $(90 \%)$ began exactly during the years of the sharp changes in the solar activity, and only two (10\%) took place a year later. The last mass reproduction of this pest was noted in 2010-2012 with its maximum number in 2010. It means that the beginning of the regular mass reproduction should be expected in 2019 (Biletskyi, 2011; Biletskyi, Stankevych, 2018).

We have developed this prognosis for the Ukrainian geographic populations in general. However the geneticists and ecologists (Dubinin, 1932; Schmalhausen, 1946) have determined that the geographical populations consist of the local ones and the prognosis at the geographical level is often not confirmed. Considering this fact we have made an analysis of the long-term dynamics of the sun pest geographic populations' number in the southern, eastern, and central regions of Ukraine and identified the local populations of this pest. According to our researches the geographic populations of the sun pests are concentrated in the Barvenkovsk, Kupiansk, Lozova and Kharkiv districts of the Kharkiv region; in the Bilovodsk, Bilokurakinsk, Svatovo and Starobielsk districts of the Luhansk region; in the Artemivsk, Volodarsk and Volnovakha districts of the Donetsk region; in the Domensk, Znamenka and Maloviskovsk districts of the Kirovograd region; in the Domashevsk, Ovidiopolsk, Reneisk and Tatarburnarsk districts of the Odessa region; in the Vasylkivsk, Kryvorizhsk, Piatykhatsk, Sofievka and Soloviansk districts of the Dnipropetrovsk region; in the Bashtansk, Bratsk, Voznesensk and Vladymyr districts of the Kherson region; in the Akimovsk, Melitopol, Mykhailivsk and Prymorsk districts of the Zaporizhzhia region; in the Vysokopolsk and Chaplynsk districts of the Kherson region; and in the Krasnohvardeisk, Starokrymsk and Feodosiia districts of the Autonomous Republic of Crimea.

To analyse the sun pest local populations' dynamics of many years we have used the reproduction rates, the weight of males and females, the sex ratio, the gender index and the percentage of the black individuals within the population as the indices (Table 1).

As it can be seen from Table 1 the reproduction rate of the sun pest population in Kupiansk varied significantly and has been increasing from 0,3 to 34 or increasing and decreasing 113 times respectively. The weight of the males varied from 94 to $128 \mathrm{mg}$. or 1,4 times; the weight of the females varied from 101 to $160 \mathrm{mg}$. or 1,6 times. The changes in the gender index were also demonstrative.

During some years the number of the males in comparison with the number of the females increased 1,3-3,5 times, especially it occurred during the years of the mass reproductions of the Kupiansk local population of the sun pest, that is in 1970, 1984-1985, 19871988, 1990-1993, and in 1996 their number increased 3,6 times. The increase in the number of the males in the local population can be explained by that fact that in 1993-1995 there was a depression in the reproduction of this local population, and during these years the reproduction rate decreased from 4 (in 1993) to 0,3 (in 1995). The ratio of the males in the population sharply increased in response to the reproduction in number in 1996 (78\%).

This fact confirms the theory of G.A. Viktorov (Viktorov, 1967) according to which the regulation in the number of the insects is an automatic and cybernetic process with the presence of the negative feedback as a mechanism.

At present the relationship between the sexual composition of the population and its number has been determined. At the same time the ecologists consider the dynamics of the sexual composition of the population as one of the adaptive mechanisms of the number regulation (Schwartz, 1980). In addition there is the evidence that shows that during the population cycle of the animals not only the number but also the age and genetic structure, physiological properties of the individuals and other population indices also are changing (Schwartz, 1980; Bolshakov, 1983). 
Table 1. Changes in the structure and number of the sun pest local population (1969-2001)

\begin{tabular}{|c|c|c|c|c|c|c|c|}
\hline \multirow{2}{*}{ Years } & \multirow{2}{*}{$\begin{array}{l}\text { Reproduction } \\
\text { rate }\end{array}$} & \multicolumn{2}{|c|}{ Weight, mg. } & \multicolumn{2}{|c|}{ Ratio, \% } & \multirow{2}{*}{ Gender index } & \multirow{2}{*}{$\begin{array}{c}\% \text { of } \\
\text { melanists }\end{array}$} \\
\hline & & males & females & males & females & & \\
\hline 1969 & 8 & 107 & 115 & 55 & 45 & 1,2 & 4,0 \\
\hline 1970 & 12 & 116 & 122 & 60 & 40 & 1,5 & 5,0 \\
\hline 1971 & 7 & 124 & 130 & 51 & 49 & 1,0 & 3,0 \\
\hline 1972 & 6 & 123 & 126 & 47 & 53 & 0,9 & 4,0 \\
\hline 1973 & 7 & 110 & 119 & 37 & 63 & 0,6 & 6,0 \\
\hline 1974 & 2 & 119 & 124 & 52 & 47 & 1,1 & 1,0 \\
\hline 1975 & 2 & 119 & 124 & 53 & 47 & 1,1 & 0,8 \\
\hline 1976 & 2 & 118 & 123 & 52 & 48 & 1,1 & 0,5 \\
\hline 1977 & 1 & \multicolumn{2}{|c|}{ no data } & 50 & 50 & 1,0 & - \\
\hline 1978 & 1 & \multicolumn{2}{|c|}{ no data } & 50 & 50 & 1,0 & - \\
\hline 1979 & 2 & \multicolumn{2}{|c|}{ no data } & 50 & 50 & 1,0 & - \\
\hline 1980 & 2 & 121 & 126 & 50 & 50 & 1,0 & - \\
\hline 1981 & 3 & 124 & 129 & 52 & 48 & 1,1 & 1,0 \\
\hline 1982 & 12 & 128 & 160 & 53 & 47 & 1,0 & 3,0 \\
\hline 1983 & 10 & 117 & 121 & 43 & 57 & 0,7 & 3,0 \\
\hline 1984 & 25 & 120 & 132 & 57 & 43 & 1,3 & 12,0 \\
\hline 1985 & 34 & 101 & 123 & 61 & 39 & 1,5 & 10,0 \\
\hline 1986 & 4 & 120 & 126 & 50 & 50 & 1,0 & 5,0 \\
\hline 1987 & 20 & 125 & 135 & 64 & 36 & 1,8 & 2,0 \\
\hline 1988 & 5 & 127 & 136 & 61 & 39 & 1,6 & 105 \\
\hline 1989 & 10 & 116 & 127 & 50 & 50 & 1,0 & 1,4 \\
\hline 1990 & 10 & 120 & 122 & 67 & 33 & 2,0 & 2,2 \\
\hline 1991 & 5 & 128 & 134 & 69 & 31 & 2,2 & 3,0 \\
\hline 1992 & 10 & 108 & 122 & 72 & 28 & 2,6 & 10,0 \\
\hline 1993 & 4 & 125 & 134 & 70 & 30 & 2,3 & 4,0 \\
\hline 1994 & 1,0 & 97 & 123 & 60 & 40 & 1,5 & 1,0 \\
\hline 1995 & 0,3 & 122 & 129 & 50 & 50 & 1,0 & 0,3 \\
\hline 1996 & 4,0 & 98 & 136 & 78 & 22 & 3,5 & 4,0 \\
\hline 1997 & 0,8 & 94 & 101 & 61 & 39 & 1,5 & 0,8 \\
\hline 1998 & 5,0 & 101 & 112 & 60 & 40 & 1,5 & 1,0 \\
\hline 1999 & 0,7 & 97 & 105 & 44 & 56 & 0,8 & 0,5 \\
\hline 2000 & 13,0 & 105 & 115 & 70 & 30 & 2,3 & 3,0 \\
\hline 2001 & 2,0 & 133 & 138 & 50 & 50 & 1,0 & 0,8 \\
\hline
\end{tabular}

Note: the gender index more than 1 means that the males dominate in the population; the gender index less than 1 means that the females dominate in the population.

The change in the ecological structure of the Izium sun pest local population is given in Table 2. The cyclical changes in the ecological structure (organization) are also characteristic of the Izium local population of the sun pest. Its sudden mass reproduction was noted by N.N. Sokolov, one of the founders of the doctrine of the sun pest. In 1901 he wrote: "In the Middle Russia the sun pest first appeared in the Kharkiv province along the middle stream of the Donets, namely in the Izium district. Then it moved to the Kupiansk and Starobielsk districts of the same province as well as to the Bakhmut district of the Yekaterinoslav province" (Sokolov, 1901).

The analyses of the dynamics of the Izium and Kupiansk local populations of the sun pest made it possible to note the time convergences of the mass reproductions as well as the wandering of the breeding grounds in the Izium local population as one of the properties of the nonlinear dynamic systems. For example from late May to mid July of 1993 the cloudy weather with high air humidity and the absence of sunshine was observed. Despite the unfavourable weather conditions the beginning of the regular increase in the number of the sun pest was noted in all districts of the Kharkiv region. The beginning of the regular mass reproduction of the sun pest in the Kharkiv region took place in 1997, when the reproduction rate of this pest amounted to 17 in the Lozova Steppe region and 16 in the Kharkiv Forest-Steppe region (Table 3). At the same time in 1997 the mass reproduction of the sun pest began in the North Caucasus. There the hibernated bugs with a density exceeding the threshold were found in an area of 1 million ha, and in some districts of the Rostov Region the density of the winged bugs of a new generation reached 60-90 specimens/ $\mathrm{m}^{2}$. In 1997 the vast areas were populated by the sun pest in the Krasnodar and Stavropol Territories, in the Lower and Middle Volga Regions. For example in 1997 in the Volgograd region the density of the new generation larvae ranged from 150 to 800 specimens $/ \mathrm{m}^{2}$ and the losses of grain caused by this pest in Russia were estimated at more than 3 million rubles. Moreover the mass reproductions of this pest were recorded in Bulgaria, Hungary, Romania, Yugoslavia, in the countries of the Middle and Far East (the wandering of the mass reproduction within the population range as one of the fundamental regulations on the aggravated rates). The favourable weather conditions of 1998 facilitated the reproduction of the sun pest in the Kharkiv region especially during the spring and summer (there was the severe drought). Nevertheless the reproduction rate of this pest as a whole in the region was 1,8 (in 1997 it was 3,9). In the Lozova district it was almost 4 times less, in the Kharkiv region it was 1,2 times less, and in the Izium district one of the oldest initial breeding grounds of the sun pest mass reproduction reached only 1 , i.e. the mass reproduction was completed.

The methodology for solving the "aggravated problems" from the nontraditional point of view considers a number of classical problems not only in meteorology (the catastrophic phenomena in the Earth's atmosphere like the severe droughts) but also in ecology. At the same time the influence of small disturbances varies depending not only on a number of factors, but also on the stage of the process development (mass reproduction) and on the location whether it falls in the center of the population localization or on its periphery. 
Table 2. Changes in the ecological structure of the Izium local population of sun pest

\begin{tabular}{|c|c|c|c|c|c|c|c|c|}
\hline \multirow{2}{*}{ Years } & \multicolumn{2}{|c|}{$\begin{array}{c}\text { Density per } \\
1 \mathrm{~m}^{2}\end{array}$} & \multirow{2}{*}{$\begin{array}{l}\text { Reproduction } \\
\text { rate }\end{array}$} & \multicolumn{2}{|c|}{ Weight, mg. } & \multicolumn{2}{|c|}{ Ratio, \% } & \multirow{2}{*}{$\begin{array}{l}\text { Gender } \\
\text { index }\end{array}$} \\
\hline & $\begin{array}{l}\text { hibernated } \\
\text { bugs }\end{array}$ & $\begin{array}{c}\text { new generation } \\
\text { larvae }\end{array}$ & & males & females & males & Females & \\
\hline 1987 & 1.0 & 2.7 & 2.7 & 123 & 130 & 42 & 58 & 0.7 \\
\hline 1988 & 0.5 & 3.9 & 7.8 & 117 & 120 & 56 & 44 & 1.3 \\
\hline 1989 & 0.5 & 2.5 & 5.0 & 116 & 123 & 48 & 52 & 0.9 \\
\hline 1990 & 0.2 & 0.5 & 2.5 & 114 & 126 & 48 & 52 & 0.9 \\
\hline 1991 & 0.2 & 0.5 & 2.5 & 119 & 132 & 45 & 55 & 0.8 \\
\hline 1992 & 0.3 & 1.8 & 6.0 & 122 & 135 & 45 & 50 & 1.0 \\
\hline 1993 & 0.2 & 2.0 & 10.0 & 119 & 130 & 50 & 50 & 1.0 \\
\hline 1994 & 0.2 & 1.8 & 9.0 & 120 & 125 & 50 & 50 & 1.0 \\
\hline 1995 & 0.3 & 1.7 & 6.0 & 135 & 140 & 50 & 50 & 1.0 \\
\hline 1996 & 0.2 & 2.0 & 10.0 & 128 & 131 & 40 & 60 & 0.7 \\
\hline 1997 & 0.3 & 6.0 & 20.0 & 110 & 120 & 50 & 50 & 1.0 \\
\hline 1998 & 0.8 & 1.0 & 1.0 & 121 & 139 & 39 & 61 & 0.6 \\
\hline 1999 & 4.0 & 5.0 & 1.0 & 105 & 109 & 45 & 55 & 0.9 \\
\hline 2000 & 0.8 & 1.0 & 1.0 & 105 & 112 & 48 & 52 & 0.9 \\
\hline 2001 & 2.1 & 5.2 & 2.5 & 111 & 118 & 45 & 55 & 0.9 \\
\hline
\end{tabular}

Table 3. Dynamics in the number of sun pest in some districts of the Kharkiv region in 1997

\begin{tabular}{|c|c|c|c|c|}
\hline District & Reproduction rate & males & females & Gender index \\
\hline Barvenkovo & 1.3 & 70 & 30 & 2.3 \\
\hline Bohodukhov & 2.2 & 44 & 56 & 0.8 \\
\hline Volchansk & 4.0 & 52 & 48 & 1.08 \\
\hline Zmiiv & 2.0 & 45 & 55 & 0.8 \\
\hline Izium & 20.0 & 42 & 58 & 0.8 \\
\hline Krasnohrad & 2.0 & 50 & 50 & 1.0 \\
\hline Kupiansk & 0.8 & 61 & 39 & 1.6 \\
\hline Lozova & 17.0 & 65 & 35 & 1.8 \\
\hline Pervomaisk & 3.8 & 33 & 67 & 0.5 \\
\hline Kharkiv & 16.0 & 74 & 26 & 2.8 \\
\hline
\end{tabular}

The mass disturbance may not play any role at all and is completely "forgotten" if at the quasistationary stage it falls on the periphery of the structure (the periphery of the geographic or local population range). Such situation arose at the beginning of the regular mass reproduction of the sun pest in 1997 (on the periphery range of the Kharkiv geographical population in Kharkiv district). Within the regional range this mass reproduction ended in 1999. But if the population number had grown so much that it exceeded the threshold of slow growth (during the period of the depression) then its growth would begin very rapidly in the aggravated rate. In this case it is practically impossible to predict the the beginning of the regular mass reproduction. This is explained by the fact that the nonlinearity of the population dynamics is the possibility of the unexpected changes in the direction of such processes; and their nonlinearity makes the common widespread prognoses and extrapolations fundamentally unreliable and insufficient.

\section{Predictability ranges of mass reproduction of harmful insects according to the methodology of nonlinear dynamics}

According to the classical (linear) methodology the dynamics of the populations is the changes in their number and population structure (organization) in space and time depending on abiotic and biotic factors. At the same time the changes can be predicted both in the perspective and retrospective. At least the prognostication in plant protection is oriented in that way when developing the annual and long-term prognoses in Ukraine. If the prognoses are not justified or the outbreaks of the mass reproductions of some widespread species of harmful insects occur "unexpectedly", then the search for the possible causes will begin. Such a situation was in Russia after the global mass reproduction of the webworm beetle in 1975 and in 1986-1988 and after the last mass reproduction of this pest in 2008-2010, the similar situation was in Ukraine in 2011-2013. Analysing this fact the Ukrainian ecologists affirmed that despite the successes achieved in studying the dynamics of the populations and despite the substantiations of the webworm beetle's periodic reproduction regularities and their synchronization with the cycles of the solar activity, this pest always appeared "unexpectedly" and "suddenly", "it keeps in fear the plant protection service and also suddenly disappears in order to reappear at a time when it is not expected (Fedorenko, 2011).

As a result of the systemic synthesis of the existing conceptual ideas about the regularities of the insects population dynamics and prognostication methods in plant protection the authors came to the following methodological conclusions:

- the existing concepts about the regularities of the insect populations dynamics and the prognostication methods in plant protection have become old-fashioned and do not meet the ideas of the modern representatives of nonequilibrium thermodynamics and synergetics (nonlinear dynamics);

- the modern ideas of the latter are presented in the fundamental publications we have considered above;

- due to these publications the dynamics of the insect populations is nonlinear and chaotic, while the positive nonlinear feedback should be considered its leading mechanism;

- temperature and precipitation, the "main" factors of linear dynamics, due to the presence of the strange attractors are not predicted reliably for a period of two weeks and especially for the next year (a season);

- the aggravated rates that arise spontaneously in any part of the insect species range and "wander" within the latter are characteristic for the insect population dynamics; 
- the prognostication by the extrapolation methods taking into account the available phytosanitary situation does not give the desired results (such predictions are practically not justified);

- new sudden, unforseen and unpredictable phenomena appear in nonlinear systems as a result of bifurcations;

- the external environment under which the processes of the population variation are taking place contains the discrete (breaking) structures, called the attractors; even slight fluctuations (temperature, precipitation, drought, sudden changes in the solar radiation, the duration of sunshine, solar activity, the introduction of new agricultural techniques, the applying of pesticides, etc.) as a result of the resonant interactions can cause an excessively rapid nonlinear increase in the number of the insects;

- the qualitative information should be used when developing the algorithms for the prognostication of the beginning of the regular mass reproduction of harmful insects. The chronicle of the mass reproduction over a long historical period meets this requirement and the years of sharp changes in the solar activity serve as a predicator (criterion);

- it is practically impossible to describe (formalise) the population dynamics at the linear level when it reaches a bifurcation point in the process of evolution. The system is found itself in a state of the deterministic chaos from which a new structure is formed in the process of self-organization. In this state the system becomes very sensitive to the stress factors, so its future trajectory becomes stochastic and almost unpredictable;

- the rebuilding of the structure (organization) covers the entire population in the localization zone. The mass reproduction may cease or spread to the entire system depending on the state of the initial localization zone which is above or below the threshold level;

- this regulation illustrates well the main problems of prognostication of the harmful insects' mass reproduction. A reliable prediction of time and place is practically impossible when the population approaches a bifurcation point (an outbreak of the mass reproduction). In this case an outbreak of the mass reproduction can take place not in Ukraine, but in other regions that are a part of the species range of a particular species of the harmful insect;

- a theoretically reliable prognosis is possible when the pest populations are in a relatively stable state or depression;

- taking this regulation into account the regular mass reproductions of the webworm beetle were reliably predicted in Ukraine in 1986 1988 and in 2011-2013 with the forestalling over 4-7 years (Biletskyi, 2004; Biletskyi, 2005; Biletskyi, 2006; Biletskyi, 2011; Biletskyi, 2015).

In 2011 the aggravated rates or the appearance of the local breeding grounds with a high density of the webworm beetle's caterpillars arose in the southern, eastern and in some central regions of Ukraine. In 2012 the number of this pest continued to increase in the above-mentioned and northern regions of the republic. The extermination measures controlling the caterpillars were carried out in the area of 460 thousand hectares. In 2013 the area populated by this pest was 2,7 times more than the aera in 2012; and the extermination measures were carried out in the area of 1 million 222 thousand hectares. In 2014 it was planned to treat about 3 million hectares, but only 93 thousand hectares were treated and it was 3,5 times less than it had been planed. Thus the year of 2013 was actually the last year of the regular mass reproduction of the webworm beetle in Ukraine.

In the Russian Federation the last outbreak of the mass reproduction also lasted three years. It began in 2008 in the Trans-Baikal Territory and then in the Siberian Federal Region where for the first time the average density of the hibernating caterpillars amounted to 8 specimens per $\mathrm{m}^{2}$. In the first half of 2010 the mass reproduction of the webworm beetle was recorded in the Altai Territory, Novosibirsk and Cheliabinsk Regions, in the republics of Khakassia and Tatarstan. In the first half of 2010 the mass reproduction of the webworm beetle was especially demonstrative in the Voronezh region. Despite the most severe drought during the mass summer and the oviposition by the females the latters had well-developed fat bodies and mature egg production (Review ..., 2011). This fact contradicts the prevailing literature opinion of the overwhelming majority of the ecologists that the lack of precipitation and low relative humidity are the main reasons of the infertility of the webworm beetle butterflies during the mass summer and their oviposition (Piatnitskii, 1936; Poliakov, 1964; Druzheliubova, 1972; Recommendations, 1983; Triebel, 1989; Dovgan, 2008).

In spite of the opinion of most studies air temperature and precipitation are not the "main factors" in the dynamics of the insect populations (Chronicle, 1878; Mokrzhetskii, 1902; Belanovskii, 1936; Belanovskii, 1940; Belanovskii, 1950; Watt, 1971; Odum, 1986; Stryhun, 2002; Review ..., 2011). In this regard the original researches at the example of a common beet root weevil were carried out by A.A. Stryhun in the central Forest-Steppe of Ukraine (Stryhun, 2002). For the period of 1970-2001 the number of the common beet root weevil varied from 1 to 11 specimens $/ \mathrm{m}^{2}$ in the spring and from 1,4 to 16,3 specimens/ $\mathrm{m}^{2}$ in the autumn. The author singled out the years of significant outbreaks of this pest for this period. They took place in 1974-1977, 1985-1987, 1994-1995 and in 2001. Having analysed the indices (the sums of the effective temperatures and the hydrothermal coefficients) for the given period he came to the conclusion that the meteorological conditions during the growing season and hibernation period do not explain the long-term changes in the population of the common beet root weevil. Thus it is not recommended to use air temperature and precipitation indices for the growing period as the predicates of the development of many years and annual phytosanitary prognoses. At the same time many researchers have shown that while prognostication (prediction) it is necessary to use the methods of statistics of the non-numerical nature objects, which has been intensively developing recently. In our case it is a chronicle of the mass reproduction of harmful insects. Herman Haken was the first one who substantiated the above-mentioned idea as the principle of the cyclic causality to the method of the order and chaos parameters.

In phytosanitary prognostication such an approach, taking into account the localization of the aggravated rates in space and time, allows developing the long-term qualitative prognoses of the beginning of the regular mass reproduction of harmful insects with the forestalling of up to 5 years. The years of sharp changes in the solar activity are used as a predicate. According to the synergetic ideas the solar activity is not a completely random process. This process is modulated by a 22-year cyclic character of magnetic field and 11 year recurrence of the Wolf numbers (W). Moreover the dynamic system that determines the solar activity ("sunny weather" according to A. Chizhevskii) contains a strange attractor, and, therefore, is sensitive to the initial conditions. Considering that the Wolf numbers are determined quite roughly, therefore no more than one cycle can be calculated (Malinetskii, 1997). It is quite enough for a qualitative prognosis answering the urgent question of when and where one should expect the beginning of the regular mass reproduction of one or another species of harmful insect.

\section{Conclusions}

In spite of the opinion of most studies air temperature and precipitation are not the "main factors" in the dynamics of the insect populations. At the same time many researchers have shown that while prognosticating (predicting) it is necessary to use the methods of statistics of the non-numerical nature objects which has been intensively developing recently. In our case it is a chronicle of the mass 
reproduction of harmful insects. In this connection it is recommended to use the scenario method of prognostication and decisionmaking in plant protection. This approach, based on the methodology of nonlinear dynamics (synergetic paradigm) makes it possible to determine in advance the breeding grounds of the aggravated rates and make the optimal decisions in plant protection. The predicted scenario will not be a prognostication of the future but the elements of an evolutionary process inherent in nature.

\section{References}

Babchuk I.V. (1983). Rekomendacii po prognozu razvitiya, rasprostraneniya i uchetu chislennosti lugovogo motylka, Kiev, Urozhaj, (in Russian).

Belanovskij I.D. (1936). Zakonomernostiv massovyh razmnozheniyah vreditelej v svyazi s meteorologicheskimi faktorami, Zoologicheskij zhurnal, 15 (2), 187-216. (in Russian).

Belanovskij I.D. (1940). O massovyh razmnozheniyah nasekomyh. Pervaya ekologicheskaya konferenciya po probleme "Massovye razmnozheniya zhivotnyh i ih prognozy", Kiev, USSR (in Russian).

Belanovskij I.D. (1950). Osobennosti massovyh razmnozhenij nasekomyh i principy ih prognozirovaniya. Vtoraya ekol.konf. po probleme "Massovye razmnozheniya zhivotnyh i ih prognozy". Kiev, KTU (in Russian).

Beleckij E. N. \& Stankevich S. V. (2018). Policiklichnost', sinhronnost' i nelinejnost' populjacionnoj dinamiki nasekomyh i problemy prognozirovanija, Vienna, Premier Publishing s.r.o. Vienna (in Russian).

Beleckij E. N., Stankevich S. V. \& Nemerickaja L. V. (2017). Sovremennye predstavlenija o dinamike populjacij nasekomyh: proshloe, nastojashhee, budushhee. Sinergeticheskij podhod. Vesti HNAU im. V. V. Dokuchaeva. Series Fitopatologija i jentomologija, 1-2, 22-33. (in Russian).

Beleckij E.N. (2006). Teoriya i tehnologiya mnogoletnego prognoza, Zashita i karantin rastenij, 5, 46-50. (in Russian).

Beletskij E. N. (2011). Massovye razmnozheniia nasekomykh. Istoriia, teoriia, prognozirovanie, Kharkov, Maidan, 172. (in Russian).

Bezpal'ko, V.V., Zhukova, L.V. \& Stankevych, S.V. (2019). Ecologically safe methods for presowing treatment of cereal seeds. Ukrainian Journal of Ecology, 9 (3), 189-197.

Bileckij Ye.M. (2004). Zakonomirnosti prognozu masovogo rozmnozhennya luchnogo metelika, Karantin i zahist roslin, 9, 11-13. (in Ukrainian).

Bileckij Ye.M. (2005). Teoriya i tehnologiya bagatorichnogo prognozu v zahisti roslin, Naukovij visnik ANVShU, Kiyiv, 3(29), 57-70. (in Ukrainian).

Bolshakov V.N. (1983). Ekologicheskoe prognozirovanie, Moskva, Znanie (in Russian).

Dovgan S.V. (2009). Modeli prognozu rozvitku ta rozmnozhennya fitofagiv, Herson, Ajlant (in Ukrainian).

Druzhelyubova T.S. \& Makarova L.A. (1972). Pogoda i prognoz razmnozheniya vrednyh nasekomyh, Leningrad, Gidrometeoizdat (in Russian).

Dubinin N.P. \& Romashov D.D. (1932). Geneticheskoe stroenie vida i ego evolyuciya. Genetiko-avtomaticheskie processy i problema ekogenotipov, Biologicheskij zhurnal, 1(5-6), 52-95. (in Russian).

Fedorenko V. (2011). Uvaga - luchnij metelik!, Propoziciya, 11, 88-91. (in Ukrainian).

Letopis Samovidca. (1878). Polnoe sobranie ruskih letopisej, Kiev (in Russian).

Lutytska, N.V., Stankevych, S.V. \& Zabrodina, I.V. (2019). Soybean insect pests: A review of Ukrainian and world data. Ukrainian Journal of Ecology, 9 (3), 208-213.

Malineckij G.G. (1997). Sinergetika, predskazuemost i determinirovannyj haos. Predely predskazuemosti, Moskva, Centr Kom, 69-130. (in Russian).

Mokrzheckij S.A. (1902). Lugovoj motylek, ego zhizn i mery borby s nim, Trudy byuro po entomologii, 3(2), 36. (in Russian).

Nakonechna, Yu.O., Stankevych, S.V. \& Zabrodina, I.V. et al. (2019). Distribution area of Hyphantria cunea Drury: the analysis of Ukrainian and world data. Ukrainian Journal of Ecology, 9 (3), 214-220.

Obzor fitosostoyaniya posevov selskohozyajstvennyh kultur v Rossijskoj Federacii v 2010 godu i prognoz razvitiya vrednyh obektov v 2011 godu. (2011). Moscow (in Russian).

Polyakov I.Ya. (1964). Prognoz rasprostraneniya vreditelej selsko-hozyajstvennyh kultur, Leningrad, Kolos (in Russian).

Pyatnickij G.K. (1936). Pogodnye usloviya i prognoz razvitiya lugovogo motylka. Trudy po zashite rastenij, seriya entomologiya, 1(15), 68. (in Russian).

Shmalgauzen I.I. (1946). Faktory evolyucii, Moscow-Leningrad, AN SSSR (in Russian).

Shvarc S.S. (1980). Ekologicheskie zakonomernosti evolyucii, Moscow, Nauka (in Russian).

Sokolov N.N. (1901). Nasekomye i drugie zhivotnye, nanosyashie vred v selskom hozyajstve. Mavrskij (gottentotskij) klop (Eurygaster maura F.) ili cherepashka, Sankt-Peterburg, Izdatelstvo Minesterstva zemli i osnovnyh imushestv. Departament zemli (in Russian).

Stankevich S. V., Beleckij E. N. \& Zabrodina I. V. (2019). Ciklicheski-nelinejnaya dinamika prirodnyh sistem i problemy prognozirovaniya: monografiya, Vankuver, Accent Graphics Communications \& Publishing (in Russian).

Stankevych S. V., Yevtushenko M. D. \& Zabrodina I. V. (2019). V.V. Dokuchaiev Scientific School of Kharkiv National Agrarian University and development agricultural entomology in XIX-XXI centuries. Ukrainian Journal of Ecology, 9 (2), 156-169.

Stankevych, S. V., Baidyk, H. V., Lezhenina, I. P., Filatov, M. O., Martynenko, V.I. (2019). Wandering of mass reproduction of harmful insects within the natural habitat. Ukrainian Journal of Ecology, 9(4), 578-583.

Stankevych S.V., Vasylieva Yu.V., Golovan L.V., Zabrodina I.V., Lutytska N.V., Nakonechna Yu.O., Molchanova O.A., Chupryna Yu.Yu., Zhukova L.V. (2019). Chronicle of insect pests massive reproduction. Ukrainian Journal of Ecology, 9 (1), 262-274.

Stankevych, S.V., Yevtushenko, M.D. \& Vilna, V.V. (2019). Integrated pest management of flea beetles (Phyllotreta spp.) in spring oilseed rape (Brassica napus L.). Ukrainian Journal of Ecology, 9 (3), 198-207.

Strigun O.O. (2002). Vpliv meteorologichnih umov na bagatorichnu dinamiku chiselnosti zvichajnogo buryakovogo dovgonosika, Zahist i karantin roslin: mizhvidoschij tematichnij naukovij zbirnik, Kiyiv, 48, 128-139. (in Ukrainian).

Stankevych S. V., Yevtushenko M. D., Vilna V. V., Zabrodina I. V., Yushchuk D. D. (2019). Efficiency of chemical protection of spring rape and mustard from rape blossom beetle. Ukrainian Journal of Ecology, 9(4), 584-598.

Tribel S.A. (1989). Lugovoj motylek. Moscow, Agropromizdat (in Ukrainian).

Turenko V. P., Bilyk M. O. \& Zhukova L. V. (2019). Pathogens of spring barley on abiotic factors in the eastern forest - steppe of Ukraine. Ukrainian Journal of Ecology, 9 (2), 179-188.

Uatt K. (1971). Ekologiya i upravlenie prirodnymi resursami, Moscow, Mir (in Russian).

Viktorov G.A. (1967). Problemy dinamiki chislennosti nasekomyh (na primere vrednoj cherepashki), Moscow, Nauka (in Russian).

Zhukova L. V., S. V. Stankevych, \& V. P. Turenko (2019). Root rots of spring barley, their harmfulness and the basic effective protection measures. Ukrainian Journal of Ecology, 9 (2), 232-238.

\section{Citation:}

Stankevych, S.V., Biletskyj, Ye.M., Zabrodina, I.V., Yevtushenko, M.D., Baidyk, H.V., Lezhenina, I.P., Filatov, M.O., Sirous, L.Ya.,Yushchuk, D.D., Melenti, V.O., Molchanova, A.O., Zhukova, L.V., Nepran, I.V., Romanov, O.V., Romanova, T.A., Bragin, O.M., (2020). Prognostication algorithms and predictability ranges of mass reproduction of harmful insects according to the method of nonliner dynamics.

Ukrainian Journal of Ecology, 191), 37-42.

\begin{tabular}{|l|l}
\hline$(c))$ EY \\
\hline
\end{tabular} 